\title{
Linfoma nasal de células T/NK
}

\author{
Nasal T/NK cell lymphoma
}

\author{
A. Torre Iturraspe1, S. Llorente Pendás², J.C. de Vicente Rodríguez ${ }^{3}$, \\ L.M. Junquera Gutiérrez², J.S. López-Arranz Arranz ${ }^{3}$
}

Resumen: El linfoma nasal de células T/ natural killer (NK) (LNT/NK), tras haber recibido múltiples denominaciones, ha sido definido y caracterizado en el año 2001 por la Organización Mundial de la Salud (OMS), basándose en una clasificación previa de la Revised European-American Lymphoma Classification (REAL), de la manera en que se le conoce actualmente. Su incidencia en el mundo occidental es baja, mientras que en Asia supone el segundo grupo de linfomas más frecuente, tras los gastrointestinales. Se localiza preferentemente en las fosas nasales y senos maxilares, mostrando un curso clínico agresivo, definido por una destrucción de los tejidos circundantes. Su diagnóstico definitivo se realiza por medio de técnicas de hibridación in situ, llegando a la determinación de su inmunofenotipo. Se ha observado una frecuente asociación con el virus de Epstein-Barr (VEB). El pronóstico de esta enfermedad viene definido por el índice pronóstico internacional (IPI) y por el volumen alcanzado por el tumor. A pesar de ser radiosensible, su pronóstico es infausto, aconteciendo la muerte del paciente poco tiempo después del diagnóstico, generalmente como consecuencia de las complicaciones del tratamiento.

Palabras clave: Linfoma nasal de células T/NK; Virus de Epstein-Barr; Hibridación in situ; Clasificación; Linfoma sinonasal.

Recibido: 26-04-2004

Aceptado: 18-11-2004
Abstract: Nasal T-cell and Natural Killer cell lymphoma (NT/NKL), having been given many names, was defined and described in the year 2001 by the World Health Organization (WHO), on the basis of a previous classification by the Revised European-American Lymphoma Classification (REAL) as it is known today. Its incidence in the western world is low, while in Asia it represents the second most frequent group of lymphomas, followed by the gastrointestinal [lymphoma]. It is typically located in the nasal cavity and maxillary sinuses. It is associated with an aggressive clinical course, characterized by the destruction of surrounding tissue. The definitive diagnosis is made by means of in situ hybridization techniques, in order to determine the immunophenotype. Its association with the Epstein-Barr virus (EBV) has frequently been observed. The prognosis of this disease is determined by the International Prognosis Index (IPI) and by the size of the tumor. In spite of being responsive to irradiation therapy, its prognosis is gloomy, and the death of the patient occurs shortly after the diagnosis, generally as a result of treatment complications.

Key words: Nasal T/NK cell lymphoma; Epstein-Barr virus; In situ hybridization; Classification; Sinonasal lymphoma.

\footnotetext{
1 Médico Residente.

2 Médico Adjunto.

3 Jefe de Sección.

Servicio de Cirugía Oral y Maxilofacial.

Hospital Universitario Central de Asturias. Oviedo, España.
}

Correspondencia:

Aintzane Torre Iturraspe.

Fuente del Prado, $11-2^{\circ} \mathrm{A}$

33009. Oviedo. España

Teléfono: 655707563

e-mail: aintza_torre@eresmas.com 


\section{Introducción}

El linfoma nasal de células T/NK (LNT/NK) fue descrito por Mc Bride en 1897, si bien hasta 1994 no se llegó a la identificación certera de la lesión ni a su clasificación como entidad independiente dentro del grupo de los linfomas no Hodgkin (LNH) con la denominación de LNT/NK. Durante este tiempo ha recibido múltiples denominaciones (Tablas 1 y 2)..$^{1-3}$ La introducción de la clasificación de la OMS, 4,5 ha generado unas condiciones que han favorecido la cooperación internacional de oncólogos y patólogos. Esta clasificación se basa, principalmente, en el comportamiento inmunohistoquímico de las células tumorales, y realiza una división morfológica según las distintas líneas celulares. Dentro de cada categoría se agrupan las distintas entidades nosológicas según su presentación clínica ofreciendo así una clasificación de «enfermedades reales» (Tabla 3). 3,6-11

Presentamos un caso de linfoma nasal de células $\mathrm{T} / \mathrm{NK}$, enfatizando en los problemas diagnósticos que habitualmente plantea esta rara entidad.

\section{Caso clínico}

Una mujer de 72 años, que acudió a consultar en Septiembre de 2000, por presentar una lesión ulcerada en la mucosa palatina de la región maxilar superior derecha, de una semana de evolución, asociada a molestias faciales homolaterales. Entre sus antecedentes destacaba una sinusitis maxilar derecha recidivante desde el año 1995, que había requerido legrado endoscópico en tres ocasiones, siendo las biopsias negativas para malignidad en todos los casos.

En la exploración se apreció la existencia de una lesión palatina ulceronecrotizante, de aproximadamente 2 $\times 2 \mathrm{~cm}$. de diámetro, con bordes imprecisos, fondo necrótico y acompañada de una erosión ósea superficial (Fig. 1). El resto de la exploración oral, facial y cervical resultó normal. No exis-
Tabla 1. Cronología de la taxonomía del LNT/NK

1897 Mc Bride describe el primer caso de linfoma centrofacial.

1933 Stewart describe la primera serie de casos adoptando el nombre de síndrome de Stewart.

1949 Williams lo denomina granuloma letal de la línea media.

1970 Se utilizan estudios de inmunohistoquímica y genética molecular para identificarlo como linfoma no Hodgkin extranodal.

1994 Primera unificación internacional de criterios realizada por el Grupo Internacional para el Estudio del Linfoma. Se introduce la clasificación REAL (Revised EuropeanAmerican Lymphoma Classification).

2001 Nueva clasificación de la OMS basada en la REAL.

Table 1. Chronology of the taxonomy of NT/NKL

1897 McBride describes the first case of centrofacial lymphoma.

1933 Stewart describes the first series of cases and the name Stewart's syndrome is adopted.

1949 Named by Williams as lethal midline granuloma.

1970 Immunohistochemical studies and molecular genetics are used to identify it as extranodal non-Hodgkin's lymphoma.

1994 First international unification of criteria carried out be the International Lymphoma Study Group. The REAL classification (Revised European-American Lymphoma Classification) is introduced.

2001 New classification of the WHO based on that of the REAL.

Tabla 2. Denominaciones del LNT/NK

- Granuloma letal de la línea media

- Ulceración granulomatosa

- Granuloma de Stewart

- Rinitis gangrenosa progresiva

- Reticulosis maligna de la línea media

- Lesión angiocéntrica inmunoproliferativa

- Granuloma maligno centrofacial

- Granuloma gangrenescens

- Reticulosis polimorfa

- Sarco lupo pernio

- Linfoma sinonasal

- Pseudolinfoma

- Linfoma angiocéntrico

- Linfoma nasal de células T/NK

Table 2. Designations for NT/NKL

- Lethal granuloma of the midline

- Granulomatous ulceration

- Stewart's granuloma

- Progressive gangrenous rhinitis

- Midline malignant reticulosis

- Angiocentric immunoproliferative lesion

- Centrofacial malignant granuloma

- Granuloma gangrenescens

- Polymorphic reticulosis

- Sarco lupo pernio

- Sinonasal lymphoma

- Pseudolymfoma

- Angiocentric lymphoma

- Nasal T/NK cell lymphoma

\section{Introduction}

Nasal T/NK cell lymphoma was described by McBride in 1897, although it was not until 1994 that the lesion was accurately identified and classified as an independent entity within the non-Hodgkin's lymphoma group, and named as Nasal T/NK cell lymphoma. During this time it has received many classifications (Tables 1 and 2) 1 . 3. Its introduction into the WHO classification 4,5 has generated conditions favoring international cooperation between oncologists and pathologists. This classification is based principally on the immunohistochemical behavior of tumor cells, and it makes a morphological division along different cellular lines. Within each category the different nosologic entities are grouped together according to clinical presentation and a classification of «real diseases» is therefore offered (Table 3).3,6-11

We present a case of nasal T/NK cell lymphoma, while emphasizing problems that arise when diagnosing this rare entity.

\section{Case Report}

A 72-year old female was presented in September 2000 with an ulcerating mucosal lesion in the right palate of the upper jaw. It had been evolving for over a week and was associated with ipsilateral facial discomfort. She had a history of maxillary sinusitis on the right side going 
tía afectación del estado general ni fiebre. En la exploración radiológica efectuada en ese momento ortopantomografía y tomografía computarizada (TC), solamente se apreció una opacificación del seno maxilar derecho, sin destrucción ósea, que dados los antecedentes de la paciente no resultó llamativo. En los análisis practicados, destacó una elevación significativa de la velocidad de sedimentación globular VSG, de $62 \mathrm{~mm}$ en la $1^{1}{ }^{\mathrm{a}}$ hora, así como una elevación de la proteína $C$ reactiva (PCR). La biopsia realizada no aportó hallazgos específicos que permitieran clasificar la lesión, ni descartar malnignidad.

Con los resultados disponibles en aquel momento, se planteó un diagnóstico diferencial con todas las lesiones ulceroproliferativas de asiento en la extremidad cefálica.

A pesar de ello, y dado que la clínica de dolor iba en aumento, se instauró un tratamiento empírico con corticoides, lográndose una leve mejoría del cuadro, que no se mantuvo en el tiempo. A los dos meses se produjo un empeoramiento, tanto del dolor como de la ulceración, que se extendió a todo el hemimaxilar derecho, incluyendo el proceso alveolar y el fondo de vestíbulo homolateral.

La TC realizada en ese momento reveló la existencia de adenopatías laterocervicales yugulares menores de $1 \mathrm{~cm}$, ocupación del seno maxilar derecho, ahora con destrucción de la pared anterior y afectación de los tejidos blandos adyacentes (Fig. 2). Se realizó entonces, una nueva biopsia en el fondo del vestíbulo derecho, siendo el resultado de síndrome linfoproliferativo tipo linfoma no-Hodgkin extralinfático T/NK. No se llegó a confirmar la presencia de VEB mediante técnicas clásicas. Tres años después, en que tras realizar una revisión de las muestras anatomopatológicas disponibles del caso, se confirmó su presencia mediante la utilización de técnicas de hibridación in situ que no habían sido utilizadas en el momento del diagnóstico. En el rastreo sistémico realizado no se apreciaron otros focos de neoplasia en el orga-
Tabla 3. Clasificación de la OMS para neoplasias periféricas de células Ty NK (2001)

Neoplasias de células T maduras (periféricas):

- Leucemia prolinfocítica de células T.

- Leucemia linfocítica granular de células T.

- Leucemia agresiva de células NK.

- Leucemia/linfoma del adulto de células T (HTLV1+).

- Linfoma extranodal de células T/NK, tipo-nasal.

- Linfoma asociado a enteropatía de células T.

- Linfoma hepatoesplénico de células gd.

- Linfoma de células T tipo paniculitis subcutánea.

- Micosis fungoide/Síndrome de Sézary.

- Linfoma periférico inespecífico de células T.

- Linfoma angioinmunoblástico de células T.

- Linfoma anaplásico de células grandes tipo cutáneo de células $\mathrm{T} /$ nulas.

- Linfoma anaplásico de células grandes, tipo sistémico de células T/nulas.

Table 3. WHO classification for T and NK cell peripheral neoplasms (2001)

\section{Mature (peripheral) T-cell neoplasms}

- T-cell prolymphocytic leukemia

- T-cell granular lymphocytic leukemia

- Aggressive NK cell leukemia

- $\quad$ Adult T-cell leukemia/lymphoma (HTLV1+)

- Extranodal T/NK cell lymphoma, nasal type.

- Enteropathy-type T cell lymphoma

- Hepatosplenic lymphoma of gd cells

- Subcutaneous panniculitis-type T-cell lymphoma

- Mycosis fungoides/Sézary's syndrome

- Peripheral T cell lymphoma, unspecified

- Angioimmunoblastic T-cell lymphoma

- Cutaneous-type anaplastic large cell lymphoma T/ nul cell

- Systemic-type anaplastic lymphoma of large cells lymphoma $T /$ nul cell

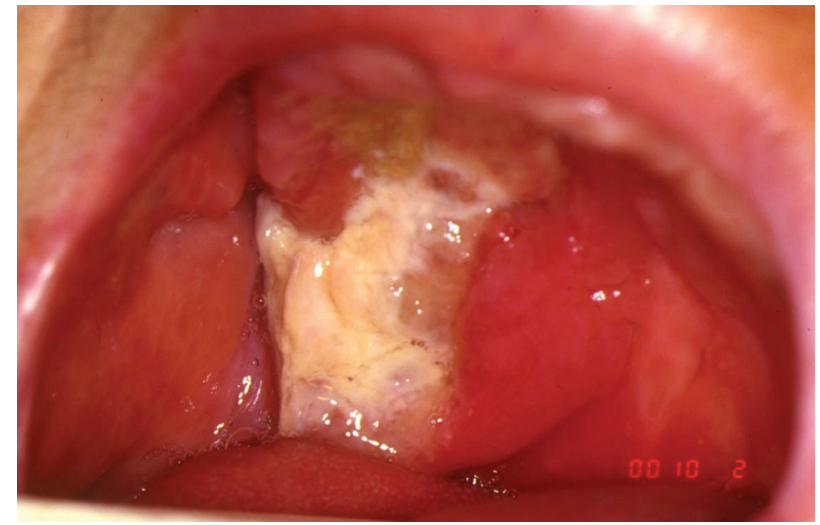

Figura 1. Lesión úlcero-necrotizante palatina. Forma de debut del linfoma T/NK del maxilar superior.

Figure 1. Ulcerative necrotic lesion of the palate. Appearance at onset of the T/NK lymphoma of the upper maxilla. back to 1995 that had relapsed. This had required endoscopic surgery on three occasions, with all biopsies being negative for malignancy.

During the examination, an ulcerative lesion of the palate was observed that measured approximately $2 \times 2 \mathrm{~cm}$ in diameter. It had indistinct borders and a necrotic base associated with erosion of bone surfaces (Fig. 1). The remaining oral, facial and cervical examination was normal. Her general health was not affected nor had she experienced a high temperature. During the radiological examination, orthopantomography and computed tomography (CT) carried out at the same time, only an opacified right maxillary sinus was observed, with no bony erosion that, given the history of the patient, was unremarkable. With regard to the tests performed, there was a significant increase in the globular sedimentation rate (GSR) of $62 \mathrm{~mm}$ during the first hour, as well as an increase in Creactive protein (CRP). The biopsy performed did not provide any specific findings enabling the classification of the lesion, nor could any malignancy be ruled out.

With the results available at the time, a differential diagnosis was given the ulcerative and proliferative lesions located in the cephalic extremity.

In spite of this, and given that the symptoms of pain were increasing, empirical treatment with corticoids 
nismo. Se instauró un tratamiento multidisciplinario con quimioterapia (QTP) de inducción y radioterapia (RTP). Se inició la QTP, a base de ciclofosfamida, doxorrubicina, vincristina y prednisona (CHOP), pero fue suspendida al segundo ciclo al constatarse una nula respuesta, con aumento de la masa tumoral. Se realizó entonces radioterapia radical, con técnica de campos opuestos laterales para llegar a dosis de 4550 Gy con Co60. La respuesta al tratamiento fue mala, produciéndose el fallecimiento de la paciente, en enero de 2001, como consecuencia de una sepsis por Pseudomona aeruginosa secundaria a la pancitopenia desencadenada por el tratamiento.

\section{Discusión}

La prevalencia del LNT/NK en Occidente es baja y representa el $1,5 \%$ de todos los LNH. Sin embargo, en Asia, supone el segundo grupo más frecuente de linfomas periféricos, inmediatamente después de los gastrointestinales, con una proporción del 2,6\% al $7 \%$ del total. Estas cifras se observan también en algunos países americanos, como México, Guatemala y Perú reforzando, según algunos autores, ${ }^{12}$ las teorías existentes sobre un posible origen común de los habitantes de estos países y los asiáticos. En los EE.UU., se ha observado un incremento de su incidencia desde 1970, en relación con el SIDA. ${ }^{13}$ Las localizaciones más frecuentes del LNT/NK son las fosas nasales y los senos paranasales, de los cuales el maxilar es el más y el frontal el menos frecuentemente afectado.

En prácticamente todas las series revisadas se observa una mayor prevalencia en varones que en mujeres, si bien no se aprecia una uniformidad en las proporciones publicadas, debido probablemente al escaso tamaño de las muestras, oscilando desde 4/1 (hombre / mujer) en Europa o 3/1 en Asia,7,12,14,15 y hasta 1,7/1 en México. ${ }^{24}$ La edad de presentación más frecuentemente observada es la sexta década de la vida, con un rango extendido entre la primera y la octava décadas.

En Occidente existe un claro predominio de los linfomas de células B sobre los de células T en el territorio cérvico-facial, constituyendo aquellos entre un 55\% y un $85 \%$ de los linfomas nasosinusales. El origen de esta diferencia geográfica no ha sido aclarado aún, si bien en algunas áreas geográficas como el sur de China, la incidencia relativamente elevada de los LNT/NK coincide con áreas endémicas de infección del VEB, el cual también se asocia con una elevada incidencia de carcinomas nasofaríngeos. En los pacientes aquejados de estos últimos, se observan elevaciones de IgA contra la cápside viral del VEB que no se observa en los pacientes con LNT/NK. En esta región también los linfomas B están asociados al VEB, lo que parece sugerir que existen was commenced. A small improvement in the symptoms was achieved, but this could not be maintained over time. Two months later there was an increase in both the pain and the ulceration that had spread to the whole of the right half of the maxilla, including the alveolar process and the back of the vestibulum on that side. The CT scan that was carried out at that point revealed the existence of laterocervical adenopathy in the neck with measuring less than $1 \mathrm{~cm}$ that were occupying the right maxillary sinus. They had by now destroyed the anterior wall and they were affecting the adjacent soft tissue (Fig. 2). A new biopsy was then taken from the back of the right vestibulum. The result given was of a lymphoproliferative syndrome that was an extranodal type of T/NK non-Hodgkin's lymphoma. The presence of EBV by means of classical techniques was not confirmed at the time. Three years later, on revising the anatomopathological samples available of the case, its presence was confirmed by means of in situ hybridization techniques that had not been used at the time of the diagnosis. Other areas of neoplasia in the organism were not visible from scans. Multidisciplinary treatment was introduced with induction chemotherapy (CT) and radiotherapy (RT). The CT was started with cyclophosphamide, doxorubicin, vincristine and prednisone (CHOP), but this was suspended during the second cycle as there was a lack of response, and the tumor mass had increased. Radical radiotherapy was then carried out, with the opposite lateral fields technique in order to reach a dose of 45-50 Gy with C060. The response to the treatment was adverse as the patient died in January 2001 as a result of sepsis due to Pseudomona aeruginosa secondary to the pancytopenia that occurred as a result of the treatment.

\section{Discussion}

The incidence of NT/NKL in the west is low and it represents $1.5 \%$ of all NHLs. However, in Asia it is the second most frequent group of peripheral lymphomas, immediately after gastrointestinal, representing 2.6 to $7 \%$ of the total. These numbers are also observed in some American countries such as Mexico, Guatemala and Peru supporting, according to some authors, ${ }^{12}$ the theories that exist as to the possible common origin of the inhabitants of these countries with Asians. In the United States an aids-related increase ${ }^{13}$ in incidence has been observed since 1970. The most com- 
factores relacionados con la localización geográfica, de mayor relevancia que la asociación a las distintas líneas celulares.

El diagnóstico de las lesiones destructivas centrofaciales se basa en la clínica y sobre todo en los hallazgos histopatológicos, si bien, dada su dificultad, es necesario un promedio de dos biopsias. ${ }^{16}$ La resonancia magnética (RM) y la TC son las técnicas de imagen más utilizadas para delimitar el estadiaje local. Las imágenes más frecuentemente observadas con estas técnicas son inespecíficas: ocupación de la cavidad nasal por grandes masas de tejido blando y erosión ósea de las paredes de los senos maxilares. La invasión del tejido blando centrofacial, orofaríngeo, infratemporal y orbitario indican un estadio avanzado (T3, T4). La erosión ósea implica un comportamiento más agresivo que el observado en el carcinoma escamoso naso-sinusal. ${ }^{17}$ La forma de presentación clínica más típica se caracteriza por obstrucción nasal y tumefacción facial (Tabla 4). Las lesiones tumorales son destructivas y pueden estar restringidas a cavidad nasal o afectar a estructuras adyacentes (nasofaringe, senos paranasales, cavidad oral). Habitualmente, la afectación de ganglios linfáticos y la sintomatología sistémica son poco frecuentes. En el caso que presentamos, existía una lesión destructiva mediofacial, pero sin afectación sistémica y con hallazgos en los estudios de imagen e histopatológicos inespecíficos. Existe, no obstante, un pequeño número de pacientes que pueden presentar manifestaciones en otras localizaciones distintas de la facial como la piel de otras partes del cuerpo, los pulmones y el tracto gastrointestinal. Este hecho sugiere, para algunos investigadores, ${ }^{18}$ que el LNT/NK pertenece en realidad a un grupo de linfomas con idéntico cuadro histológico y clínico, siendo sus diversas localizaciones (pulmonar, intestinal, dermatológica) manifestaciones diferentes de una misma enfermedad.

El diagnóstico definitivo de esta entidad es histopatológico. Es característico que las biopsias realizadas no presenten, en una valoración inicial, indicios de malignidad, lo que podría deberse al escaso tamaño de las muestras obtenidas en las biopsias. Pero el hecho es que la biopsia se positiviza cuando es repetida en fases avanzadas de la enfermedad, cuando esta presenta signos destructivos clínicos y radiológicos. En definitiva, los LNT/NK muestran un curso clínico agresivo y un modelo de progresión extralinfático. En los niños la afectación sistémica y respiratoria es más frecuente pudiendo presentar incluso úlceras faríngeas. ${ }^{1}$ La imagen histológica de los LNT/NK se caracteriza por presentar invasión vascular, necrosis y presencia de células inflamatorias. Si bien la invasión vascular es un hallazgo inconstante, la necrosis no lo mon site for NT/NKL is the nasal cavity and paranasal sinuses, the maxillary being the most frequently involved and the frontal the least.

In practically all the series revised, a higher prevalence in males than in females has been observed, although no consistency can be appreciated in the ratios published due probably to the limited size of the studies. This has varied between $4 / 1$ (male/female) in Europe and $3 / 1$ in Asia $7,12,14,15$ and up to 1.7/1 in Mexico. ${ }^{24}$ The most frequently observed age at presentation is in the sixth decade of life, with ranging from the first to the eighth decade. In the West there is a clear predominance of $B$-cell lymphomas over T-cell lymphomas in the cervico-facial region, the former representing between $55 \%$ and $85 \%$ of all sinonasal lymphomas. The origin of this geographic difference is still unclear, although in some geographic areas such as the south of China the incidence of NT/NKL is relatively high, coinciding with areas endemic for $E B V$ infection also associated with a high incidence of nasopharyngeal carcinoma. Elevated IgA against EBV viral capside has been observed in these last patients, but not in patients with NT/NKL. In this region B lymphomas are also associated with EBV, which would suggest that factors related with geographical location are of greater relevance than the association of different cellular lines.

The diagnosis of destructive midface lesions is based on clinical and more especially on histopathological findings, but since this is difficult, at least two biopsies are needed..$^{16}$ Magnetic resonance (MR) and CT scans are the imaging techniques most used to depict local staging. The images most frequently observed with these techniques are not very clear: the extent of the invasion of the nasal cavity by large masses of soft tissue, and bony erosion of the maxillary sinus walls. The invasion of midface, oropharyngeal, infratemporal and orbital soft tissues indicates an advanced stage $(T 3, T 4)$. Bony erosion implies behavior that is more aggressive than that observed in the sinonasal squamous cell carcinoma. ${ }^{17}$ The typical clinical presentation is characterized by nasal obstruction and facial swelling (Table 4). These tumor lesions are destructive. They may be confined to the nasal cavity or they may affect adjacent structures (nasophar- 
es, y probablemente se debe a la propia angioinvasión o a la expresión de un factor de necrosis tumoral (TNF) inducido por el VEB. ${ }^{5}$ Este es un dato común a otras afecciones relacionadas con este virus como la mononucleosis infecciosa, la enfermedad linfoproliferativa post-transplante y la granulomatosis linfomatoide, si bien es éstas, el VEB se expresa en linfocitos $B$ y no en células $T$. El diagnóstico se dificulta por la presencia constante de un infiltrado polimorfo de células inflamatorias benignas de cualquier tamaño, que incluyen neutrófilos, histiocitos y linfocitos atípicos de pequeño y mediano tamaño. En la Tabla 5 se recoge el inmunofenotipo más frecuente. Para su determinación se utilizan técnicas de hibridación in situ, ya que las técnicas clásicamente empleadas con anticuerpos monoclonales, presentan un elevado porcentaje de falsos negativos (Fig. 3). 4,11,19 Mediante esta técnica se demuestra la presencia del VEB, incluso en casos en los que la muestra tisular posea un escaso número de células neoplásicas. Este hecho sugiere su posible futura utilización como técnica de diagnóstico aproximativo inicial. ${ }^{20}$ Algunos investigadores, 10,23 han sugerido un origen monoclonal para las células NK, basándose en análisis inmunohistoquímicos, con expresión de marcadores de las células NK, como el CD 56

$y$, en un elevado número de casos, ausencia de las cadenas $\alpha / \beta$ y $₹ / \delta$ de los receptores de células $T$ y del complejo CD3. Recordemos que las células NK son células linfoides que carecen de receptores de antígenos tradicionales como «receptores para células T» (TCR) o CD3, presentan marcadores CD16 y CD56 y una actividad citolítica innata que no precisa una sensibilización previa ni la presencia de moléculas de histocompatibilidad tipo I para que se lleva a cabo. Seki y cols. ${ }^{19}$ concluyen, tras estudiar muestras analizadas en el sur de Japón, que el LNT/NK está constituido por una mezcla heterogénea de distintos tipos celulares pero corresponde inmunofenotípica e inmunohistoquímicamente a líneas celulares NK y no de células T, lo que apoya el origen monocelular de esta entidad linfoproliferativa en las células NK.

Los LNT/NK son tumores radiosensibles en los que es posible lograr un control local de la enfermedad, aunque la recidiva es la norma en la mayoría de las series publicadas. ${ }^{21}$ Existe un consenso unánime sobre la utilización conjunta de radio (RTP) y quimioterapia (QTP) en estadios avanzados, 15,22,23 si bien en fases iniciales, la quimioterapia no parece aportar una mejoría adicional ynx, paranasal sinuses, oral cavity). The involvement of lymphatic glands and systemic symptomatology is not very common. In the case we present there was a midfacial destructive lesion, but no systemic involvement, while the imaging and histopathological studies were nonspecific. Nevertheless, a small number of patients can present symptoms in other non-facial areas such as on the skin in other areas of the body, in the lungs and in the gastrointestinal tract. For some investigators, ${ }^{18}$ this fact suggests that the NT/NKL belongs in reality to a group of lymphomas with identical histological and clinical settings, and that the various sites (lungs, intestine, skin) are different manifestations of the same disease.

The definitive diagnosis of this entity is histopathological. A characteristic of the initial assessment is for the biopsies not to show any signs of malignancy. This could be due to the limited size of the samples obtained during the biopsies. But the fact is that the biopsy is classified as positive on being repeated during the advanced stages of the disease, when it is giving destructive signs clinically and radiologically. In short, NT/NKL show an aggressive clinical course and an extranodal pattern of progression. Systemic and respiratory complaints are more common in children, and pharyngeal ulcers may also appear. The histological imaging of NT/NKL typically shows vascular invasion, necrosis and the presence of inflammatory cells. Although vascular invasion is an inconsistent finding, necrosis is not and it is probably due to the invasion itself of blood vessels or to a tumor necrosis factor (TNF) expression induced by the EBV..$^{5}$ This is a common factor in other ailments related with this virus such as infectious mononucleosis, post-transplant lymphoproliferative disease and lymphomatoide granulomatosis, although in the latter the EBV induces expression in B lymphocytes and not in $T$-cells. Diagnosis is hampered because of the constant presence of a polymorphic infiltrate of benign inflammatory cells 
de la supervivencia respecto a la utilización de la RTP aislada. Este comportamiento difiere del de los $\mathrm{LNH}$ «no centrofaciales» en los que la terapia conjunta aumenta la supervivencia. ${ }^{19}$ Algunos autores, 16,24 han observado en estudios prospectivos, que la QTP usada como tratamiento primario ocasiona un elevado riesgo de hemorragia y complicaciones sépticas, por lo que proponen su uso tan solo como tratamiento coadyuvante. El protocolo de QTP más utilizado es el CHOP. Las combinaciones de segunda (5-fluoruracilo, metotrexate, arabinósido de citosina, ciclofosfamida, vincristina y prednisona o F-MACHOP; ciclofosfamida, doxorrubicina, etopóxido, mecloretamina, vincristina, prednisona, procarbacina, metotrexate y leucovorina o PROMACE-MOPP) o tercera generación (metotrexate, doxorrubicina, ciclofosfamida, vincristina, prednisona y bleomicina o MACOP-B) no han demostrado ser mejores que las iniciales en cuanto a la tasas de remisiones completas y supervivencia. La dosis de RTP que proporciona un mejor control local es superior a 45$50 \mathrm{~Gy}$, independientemente del volumen tumoral. ${ }^{23}$ Otra posibilidad terapéutica es la utilización de un transplante de médula ósea asociado a QTP ablativa, lo que parece mejorar el control de la recidiva local tras el fracaso del tratamiento convencional con QTP. Los clásicos factores pronósticos son las características histológicas y el estadiaje en el momento del diagnóstico. Sin embargo, el factor predictivo de progresión más ampliamente aceptado hoy es el IPI, 18,25 obtenido como resultado de un proyecto para el desarrollo de sistemas de clasificación para los LNH agresivos y que utiliza criterios clínicos que reflejan el potencial invasivo del tumor (Tabla 6). Existe un modelo simplificado para los menores de 60 años puesto que la edad es un factor pronóstico. El sexo, sin embargo, parece no estar asociado con la supervivencia. El volumen tumoral (que, sin embargo, no se contempla en el IPI) es considerado por algunos autores, ${ }^{23}$ como factor pronóstico independiente para el linfoma agresivo localizado.

La mayoría de los pacientes mueren pocos meses después del diagnóstico como consecuencia de las complicaciones del tratamiento (RTP y QTP), habitualmente por cuadros sépticos debido a la inmunosupresión. ${ }^{26,27}$
Tabla 6. Parámetros del índice pronóstico internacional

Edad

- " 60 años

- >60 años

- Estadio avanzado de Ann Arbor:

- I o II

- III o IV

- Localizaciones extralinfáticas

$->1$

- Estado físico del paciente

- Tratamiento ambulatorio (0: actividad habitual, 1: tratamiento ambulatorio), o

No tratamiento ambulatorio ( 2 encamado $<50 \%$ de te encamado), o

Niveles séricos incrementados de Lactato Dehidrogenasa $(\mathrm{LDH})$

- "límite superior del rango de normalidad

Estratificación de los grupos de riesgo: 0-1 riesgo bajo, 2 riesgo bajointermedio, 3 riesgo intermedio-alto, 4-5 riesgo elevado.

Table 6. Parameters of the International Prognosis Index

- Age

- "60 years

- >60 years

- I or II

- III or IV

- Extranodal site

$-<1$

- Physical condition of the patient

- Treatment as an outpatient (0: normal activity, 1: treatment as an out patient), or

- Treatment as an inpatient ( 2 bedridden $<50 \%$ of the time, 3 bedridden $>50 \%$ of the time, 4 totally bedridden), or

- " upper limits of normal

- > lupper limits of normal

Risk group grading: 0-1 low risk, 2 low-intermediate risk, 3 intermediate-high risk, 4-5 high risk. of various sizes, which include neutrophils, atypically small or medium sized histiocytes, and lymphocytes. Table 5 collects the more frequently found immunophenotype. In situ hybridization techniques are used to determine them, as the techniques traditionally used with monoclonal antibodies have a high percentage of false negatives (Figure 3). $4,11,19$ By using this technique the presence of the EBV can be demonstrated, even in cases where the tissue sample has a limited number of neoplastic cells. This suggests that it could be used in the future as a diagnostic technique. 20 Some investigators ${ }^{10,23}$ have suggested that NK cells have a monoclonal origin, based on immunohistochemical analysis, with the expression of NK cell markers, such as CD56, and in a high number of cases, absence of the $\alpha / \beta$ y $\gamma / \delta$ chains of the $T$ cell receptors and the $C D 3$ complex. We should remember that NK cells are lymphoid cells that do not have the traditional antigen receptors such as " $T$ cell receptors" (TCR) or CD3. They have CD16 and CD56 markers and natural cytolytic activity that does not require prior sensitization or the presence of class 1 histocompatibility molecules for carrying out this process. Seki et al. ${ }^{19}$ concluded, after studying samples analyzed in the south of Japan, that the NT/NKL is made up of a heterogeneous mixture of different cellular types, but that from a immumophenotypic and immunohistochemical status it belongs to NK cellular lines and not T-cell, which supports the monocellular origin of this lymphoproliferative entity in NK cells.

NT/NKL are radiosensitive tumors and local control of the disease is possible, although in the majority of the series published there is a pattern of relapse. ${ }^{21}$ There is unanimous consensus as to the use of combining radiotherapy (RT) with 


\section{Bibliografía}

1. Vidal RW, Devaney K, Ferlito A, Rinaldo A, Carbone A. Sinonasal malignant lymphomas: a distinct clinicopathological category. Ann Otol Rhinol Laryngol 1999;108:411-9.

2. Borges A, Fink J, Villablanca P, Eversole R, Lufkin R. Midline destructive lesions of the sinonasal tract: simplified terminology based on histopathologic criteria. Am J Neuroradiol 2000;21:331-6.

3. Jakic-Razumovic J Aurer I. The World Health Organization classification of lymphomas. Croat Med / 2002;43:527-34.

4. Arrowsmith ER, Macon WR, Kinney MC, Stein RS, Goodman SA, Morgan DS y cols. Peripheral T-cell lymphomas: clinical features and prognostic factors of 92 cases defined by the revised European American lymphoma classification. Leuk Lymphoma 2003;44:241-9.

5. Vidal RW, Devaney K, Ferlito A, Rinaldo A, Carbone A. Sinonasal malignant lymphomas: a distinct clinicopathological category. Ann Otol Rhinol Laryngol 1999; 108:411-9.

6. Jaffe S E, Chan JKC, Ih-Jen Su, Frizzera G, Mori S, Feller AC y cols. Report of the workshop on nasal and related extranodal angiocentric T/Natural Killer ell lymphomas. Am J Surg Pathol 1996;20:103-11.

7. Hatta C, Ogasawara H, Okita J, Kubota A, Ishida M, Sakagami M. Non-Hodgkin's malignant lymphoma of the sinonasal tract-treatment outcome for 53 patients according to REAL classification. Auris Nasus Larynx 2001;28:55-60.

8. Harris NL, Jaffe ES, Diebold J, Flandrin G, Muller-Hermelink H, Vardiman J. Lymphoma classification-from controversy to consensus: the R.E.A.L. and WHO Classification of lymphoid neoplasms. Ann Oncol 2000;11:3-10.

9. Harris NL, Jaffe ES, Diebold J, Flandrin G, Muller-Hermelink HK, Vardiman J, y cols. The World Health Organization classification of neoplasms of the hematopoietic and lymphoid tissues: report of the Clinical Advisory Committee meeting-Airlie House, Virginia, November, 1997. Hematol / 2000;1:53-66.

10. Noorduyn LA, Torenbeek R, van der Valk P, Snow GB, Balm AJH, Ossenkoppele GJ y cols. Sinonasal non-Hodgkin's lymphoma and Wegener's granulomatosis: a clinicopathological study. Vircows Archiv A Pathol Ana 1991;418:235-40.

11. Jaffe ES. Classification of natural killer (NK) cell and NK-Like T-cell malignancies. Blood 1996;87:1207-10.

12. Gaal K, Sun NC, Hernandez AM, Arber DA. Sinonasal NK/T-cell lymphomas in the United States. Am / Surg Patho 2000;24:1511-17.

13. Hanna E, Wanamaker J, Adelstein D, Tubbs R, Lavertu P. Extranodal lymphomas of the head and neck. A 20-year experience. Arch Otolaryngol Head Neck Surg 1997;123:1318-23.

14. Cleary KR, Batsakis JG. Sinonasal Lymphomas. Ann Otol Rhinol Laryngol 1994; 103:911-14.

15. Cuadra-Garcia I, Proulx GM, Wu CL, Wang CC, Pilch BZ, Harris NL, y cols. Sinonasal lymphoma: a clinicopathologic analysis of 58 cases from the Massachusetts General Hospital. Am J Surg Pathol 1999;23:1356-69.

16. Sobrevilla-Calvo P, Meneses A, Alfaro P, Bares JP, Amador J, Reynoso EE. Radiotherapy compared to chemoterapy as initial treatment of angiocentric centrofacial lymphoma (polymorphic reticulosis). Acta Oncológica 1993;32:69-72.

17. Ooi GC, Chim CS, Liang R, Tsang KWT, Kwong YL. Nasal T-cell/Natural Killer cell lymphoma: CT and MR imaging features of a new clinicopathologic entity. Am J Radiol 2000;174:1141-5.

18. Yang Y, Gau JP, Chang SM, Lin TH, Ho KC, Young JH. Malignant lymphomas of sinonasal region, including cases of polymorphic reticulosis: a retrospective clinicopathologic analysis of 34 cases. Cin Med J (Taipei) 1997;60:236-44.

19. Seki D, Ueno K, Kurono Y, Eizuru Y. Clinicopathological features of Epstein-Barr chemotherapy (CT) for advanced stages $15,22,23$ although during the initial stage, chemotherapy does not appear to lead to an improvement in survival compared with RT on its own. This behavior differs from "non-centrofacial" NHL where joint therapy increases survival. ${ }^{19}$ Some authors ${ }^{16,24}$ have observed in prospective studies, that primary CT leads to a high risk of hemorrhage and sepsis complications, and they recommend its use only as coadjuvant therapy. The protocol used most often in CT is CHOP. The combination of second (5-fluorouracil, methotrexate, cytosine arabinoside, cyclophosphamide, vincristine y prednisone o F-MACHOP; cyclophosphamide, doxorubicin, etoposide, mechlorethamine, vincristine, prednisone, procarbazine, methotrexate y leucovorin or PROMACE-MOPP) or third generation (methotrexate, doxorubicin, cyclophosphamide, vincristine, prednisone y bleomycin or MACOP-B) have not demonstrated being better than the first with regard to complete remission and survival rates. The RT doses achieving the best local control are above 45-50 Gy, independent of the tumor size. ${ }^{23}$ Another therapeutic possibility is the practice of receiving a bone marrow transplant together with ablative $C T$, which appears to improve control during a local relapse following failure of conventional treatment with CT. The prognosis factors traditionally used are the histological characteristics and staging upon diagnosis. However, the predictive factor for progression most widely accepted today is the IPI, ${ }^{18,25}$ which was the result of a project for the development of classification systems for aggressive NHL, which uses clinical criteria reflecting the invasive potential of the tumor (Table 6). There is a simplified model for those under the age of 60, as age is a prognostic factor. Gender, however, does not appear to be associated with survival. Tumor size (which is not however contemplated in the IPI) is considered by some authors ${ }^{23}$ as an independent prognosis factor for localized aggressive lymphoma.

Most patients die a few months after diagnosis as a result of treatment related complications (RT and CT), common- 
virus associated nasal T/NK cell lymphomas in southern Japan. Auris Nasus Larynx 2001;28:61-70.

20. Jaffe S E. Nasal and nasal-type T/NK cell lymphoma: a unique form of lymphoma associated with the Epstein-Barr virus. Histopathology 1995;27:581-83.

21. Van Gorp J, de Bruin PC, Sie-Go DMDS, van Heerde P, Ossenkoppele G], Rademakers LHP, y cols. Nasal T-cell lymphoma: a clinicopathological and inmunophenotypic analysis of 13 cases. Histopathology 1995;27:139-48.

22. Donato V, lacari V, Zurlo A, Nappa M, Martelli M, Banelli E, y cols. Radiation therapy and chemotherapy in the treatment of head and neck extranodal non-Hodgkin's lymphoma in early stage with a high grade of malignancy. Anticancer Research 1998;18:547-54.

23. Shikama $N$, Ikeda $H$, Nakamura S, Oguchi M, Isobe $K$, Hirota S, y cols. Localized aggressive non-Hodgkin's lymphoma of the nasal cavity: a survey by the Japan Lymphoma Radiation Therapy Group. Int J Radiat
Oncol Biol Phys 2001;51:1228-33.

24. Meneses García A, Súchil Bernal L, de la Garza Slazar J, Gómez González E. Linfomas angiocéntricos centrofaciales de células T/NK. Aspectos histopatológicos y algunas consideraciones clínicas de 30 pacientes del Instituto Nacional de Cancerología, México. Cir Ciruj 2002;70: 410-16.

25. The International Non-Hodgkin's Lymphoma Prognostic Factors Project. A predictive model for agressive Non-Hodgkin's lymphoma. $N$ Engl J Med 1993; 329:987-94.

26. Proulx GM, Cuadra-Garcia I, Ferry J, Harris NL, Greco WR, Kaya U, y cols. Lymphoma of the nasal cavity and paranasal sinuses. Treatment and outcome of early-stage disease. Am / Clin Oncol 2003;26:6-11.

27. Prellat J, Sweetenham J, Pickering RM, Brown L, Wilkins B. A singlecentre study of treatment outcomes and survival in 120 patients with peripheral T-cell non-Hodgkin’s lymphoma. Ann Hematol 2002;81:26772. 